\title{
ACCESS OF COOPERATIVES TO THE TAX INCENTIVE FOR INNOVATION IN BRAZIL
}

\section{Acesso das cooperativas ao Incentivo Fiscal à Inovação no Brasil}

Aziz Eduardo Calzolaio

E-mail: aecalzolaio@ucs.br

Doctor (SandwichDoctorate)atScuolaSuperioreSant'Ana-Pisa, Italy; DoctorinEconomicsatFederalUniversity of Rio Grande do Sul, Brazil; Professor of Caxias do Sul Universirty.

Mailing information for contact:

Rua Francisco Getúlio Vargas, 1130. CEP 95070-560 - Caxias do Sul, RS, Brasil.https://orcid.org/0000-0001-

$7215-8833$

Heitor Jose Cademartori Mendina

E-mail: heitor-mendina@sescooprs.coop.br

Doctorin Business AdministrationatValedoRiodosSinos University; Masters DegreeinEducationatCatholic

Pontifical University of Rio Grande do Sul, Brazil;

Professor at Faculdade de Tecnologia do Cooperativismo.

https://orcid.org/0000-0003-1457-5633

Artigo recebido em 25 de julho de 2018. Aceito em 16 de julho de 2019. 
The objective of the present paper is to elucidate the practices performed by farming cooperatives regarding the tax, accounting and administrative management linked to the Tax Incentive for Innovation (TII). In this sense, the relation between the tax regime of cooperatives and access to TII was investigated. For a better understanding of this, a research of qualitative nature, whose investigation method was the single case study, was performed, in which the analysis unit was a Brazilian Agroindustry Cooperatives Central. Such Central comprehends a group of 30 agroindustry cooperatives and has the largest industrial park of powdered milk in Latin America. Besides that, such organization houses Research \& Development ( $R \& D)$ department. As a result, it was inferred that the policies that regiment the incentive for innovation confront the nature of cooperatives, decreasing the capacity such organizations have in the appropriation of this policy. Thus, there is a reducer factor in the participation of cooperatives in TII. Hence, it is suggested a debate involving the diverse actors in the innovation system, in which cooperatives are involved, to decide if such reducer factor must be overcome or accepted. Finally, the tax, accounting and administrative management that routinely operates in the Central was able to respond to the new specific procedures related to the use of the policy in debate, without the implementation of new processes.

Keywords: Agricultural cooperatives. Tax Incentive for Innovation. Cooperate Act. Taxation. Organization and management.

\section{Resumo}

O objetivo deste artigo é elucidar as práticas realizadas pelas cooperativas agropecuárias quanto à gestão tributária, contábil e gerencial vinculada ao Incentivo Fiscal à Inovação (IFI). Nesse sentido, investigou-se a relação entre o regime tributário das cooperativas e o acesso ao IFI. Para entender isso melhor, realizou-se uma pesquisa de natureza qualitativa cujo método de investigação selecionado foi o de estudo de caso único, sendo a unidade de análise uma Central de Cooperativas Agroindustriais brasileira. Tal Central congrega um conjunto de 30 cooperativas agroindustriais e possui o maior parque industrial de leite em pó da América Latina. Além disso, tal organização aloja um departamento de Pesquisa e Desenvolvimento ( $P \& D)$. Como resultado, inferiu-se que os dispositivos que normatizam - incentivo à inovação se confrontam com a natureza das cooperativas, diminuindo a capacidade que essas organizações possuem para se apropriar dessa política. Assim, existe um fator redutor da participação das cooperativas no IFI. Com isso, sugere-se um debate envolvendo diversos atores do sistema de inovação no qual as cooperativas estão envolvidas para decidir se tal fator redutor deve ser superado ou aceito. Por fim, a gestão contábil, administrativa e gerencial, que já era rotineiramente operacionalizada na Central, foi capaz de atender aos novos procedimentos específicos relacionados à utilização da política em debate, sem a implementação de novos processos.

Palavras-chave: Cooperativas agrícolas. Incentivo Fiscal à Inovação. Ato Cooperado. Tributação. Organização e gestão.

\section{INTRODUCTION}

The main goal of the present paper is to elucidate the practices performed by farming cooperatives regarding tax, accounting and administrative management necessary to deal 
with the Tax Incentive for Innovation (TII). Such policy is still little known in the universe of Brazilian cooperatives. Thus, the understanding of such benefit is relevant, given its relevance to organizational decisions. Therefore, such topic is still a challenge for academic research, in face of the rapid technological changes and their impact on the formulation of economic policies. Furthermore, given the scarceness of studies about the topic in the context of cooperatives, it can contribute to a field of study still in initial stage in Brazil and in other developing countries.

The present paper analyzes a case study about the access to a Central of Agroindustry Cooperatives in the State of Rio Grande do Sul-Brazil-to the TII. So, it was delineated the main requirements to use such policy. In this sense, the main analytical controls used by the Central to obtain success in the obtaining of tax benefits in question were analyzed.

The public incentive for innovation is a tool that aims at directing Science \& Technology $(S \& T)$ activities in order to stimulate efforts in innovation of organizations. Besides, it also aims at potentializing economical application of knowledge generated in development and research centers (Cimoli, Ferraz, \& Primi, 2005). In this sense, tax policy to incentive for innovation is a tool used by the Brazilian government aiming at enlarging the quantity and quality of innovation activities in order to boost the innovation and productivity. Such public policy is investigated in this paper specifically in the scope of farming cooperatives, seen as rural or grazing and fishing producer' associations whose means of production of the raw material belong to the cooperative members (Bialoskorski, 2016). Furthermore, the unit of analysis chosen was an agroindustry.

In Brazil, the TII was reformed by means of Law 11.196/05 (Lei 11.196, 2005). It was regulated by Decree 5.798/06 (Lei 5.798, 2006). Afterwards, the Normative Instruction 1.187/11, of the Brazilian Federal Revenue, regimented the Tax Incentives for Research Activities and Development of Technological Innovation (Instrução Normativa 1.187, 2011).

Since the tax system interferes in the fiscal policy of innovation (Warda, 2005), the induction of innovation in the cooperatives by means of the fiscal policy depends on the tax structure of such organizations. In this case, it is necessary to discern the economic transactions performed by them, segregated in cooperative act and non-cooperative act (both regarded on section 2), according to Brazilian Law (number 5.764 published in 1971) (Lei 5.764, 1971).

On the one hand, acts celebrated between the cooperative and its associates or viceversa, as well as amongst cooperatives, are cooperative acts. This type of act is characterized as a non-market act. Consequently, the operations resulting of the cooperate acts are tax immune. On the other hand, non-cooperative act occurs in the instant the cooperatives

Schneider (2010): ". . . cooperative is an autonomous association of people that voluntarily unite to satisfy aspirations and economic, social and cultural needs in common, by means of a company of collective property and democratically managed" (p. 41). 
perform transaction economics with non-associates (Lei 5.764, 1971). Since non-cooperative act is a normal market operation, then, it suffers tax effect. In this way, the paper explains how this cooperatives operations structure impacts the quantity of benefits received by cooperatives. In few words, the main result is the presence of a restrictive factor which have leaded to the diminish of the benefits from TIl for cooperative. Moreover, this restriction doesn't affect other types of firms.

The study about the effect of TII on cooperatives is relevant because of importance of that organizations on the Brazilian economy. According to data from Organização das Cooperativas Brasileiras (the Brazilian Cooperatives Organization), from 2017, the country has 6,6 thousand cooperatives, in 13 different branches, with more than 13,2 million associated and with capacity of generating about 376 thousand jobs (Organização das Cooperativas Brasileiras $[O C B], 2017)$. More specifically, 1,555 cooperatives are of the farming branch. They are responsible for more than $40 \%$ of the GDP of agrobusiness in Brazil (OCB, 2017). Moreover, they congregate more than 1 million cooperates and generate about 189 thousand jobs. Furthermore, Brazilian cooperatives export US\$ 5,1 billion to 147 countries, registering a positive worth in the Brazilian trade balance in 2016 (Organização das Cooperativas do Rio Grande do Sul [OCERGS], 2017). However, even with this important, only 4 cooperatives used TII in 2014, a signal of the little involvement of such organizations with the innovation policy in Brazil.

The TII can reduce costs and increase productivity of cooperatives, resulting in major resources for them to invest in technological and innovative projects. Besides that, such policy can make more efficient the infrastructure of cooperatives in the areas such as information technology, technical assistance and communication. Consequently, it can improve the operational processes, human capacities, and physical capacities of storage in silos. Moreover, since R\&D is a part of the routine of many cooperatives sectors-such as hydroelectric power stations, housing, transportation and new hospitals-TII may improve the research activities in these sectors. So that, the cooperatives can reduce its innovation cost by use of TII. Therefore, the research question is: what are the practices to deal with tax, accounting and administrative management perform by farming cooperatives in order accesses the TII?

Besides this section, the bibliography about innovation and taxation in cooperatives is presented on section 2. Subsequently, the methodology is presented on section 3. Later, the data analyzed is on section 4. Finally, the conclusions are exposed on section 5. 


\section{THEORETICAL REFERENCE}

\subsection{FISCAL INCENTIVE AND INNOVATION IN COOPERATIVES}

Brazilian cooperatives used few fiscal incentives until the decade of 2000. Likewise, the big capitalist companies have accessed a lot of public incentives (Triguero-Cano \& Cuerva Narro, 2011). Such tendency of greater fiscal support to large corporations to the detriment of cooperatives is verified by the finding that only 4 cooperatives used the TII in 2014, in Brazil, amongst 1,206 capitalist organizations that were benefited from.

The strategic directives that allow competitive advantage help maintain organizations and improve their performance (Caldeira, 2007; Ganiyu, Barbara, \& Paul, 2018). One of these directives is the innovation for the Brazilian agri-food industry. This economic sector invests in advance technology in order to manufacture its production. Moreover, it performances R\&D and invests in intangible amounts (Triguero-Cano \& Cuerva Narro, 2011).

Organizations that innovate improve their market positions, besides reaching extraordinary profits. Meanwhile, the ones that do not do such, tend to lose clients and bankrupt (Schumpeter, 1982). In this case, the economic environments become more dynamic and incited to transformations (Silva, 2017). Hence, inventions are primordial to national competitivity, growing and development (Grazzi \& Pietrobelli, 2016). Therefore, the investment in $R \& D$ improves the performance of organizations (Lome, Heggeseth, \& Moen, 2016).

The uncertainty is a feature of innovation because there is risk that an embryonic research results in failure. In this case, companies that invested in innovation may suffer losses (Nelson, 2006; Bowers \& Khorakian, 2014). Besides that, even with innovation success, a new creation may have the possibility of functioning differently from initially planned. In other words, the final good invented has certain degree of unpredictability regards its function practical. Therefore, there is a conjunct of uncertainties in the process of development of an innovation. Hence, the production sector has much insecure in investing in such activity. Furthermore, the time necessary for a research to be applied in the development of a product and it results in profit is too long. This lag time is bigger of that one which normally the entrepreneur to wait in order to reach his profit (Nelson, 2006; Freeman \& Soete, 2008). At the same time, the cost of an innovation project is high (Rosenberg, 2006).

Because there are restrictions and barriers to performance innovations, the innovation policy aims at overcoming these obstacles. In the face of, the government provides even funding solutions. In summary, the public incentives, as the tax incentives, balance the risks and uncertainties intrinsic on innovation activities (Freeman \& Soete, 2008). 
In 2005, a new Brazilian model of Tax Incentive for Innovation was introduced through Law 11.196/05 (Lei 11.196, 2005). Such policy can be used by companies that spend on R\&D, hire researchers and register of patents and cultivars. So, the expenditure generate through those activities are eligible to be benefited by TII as long as they are performed inside the company or spent both with university and with Microenterprise and Small Business or independent consultant.

The Normative Instruction 1.187/11 of the Brazilian Federal Revenue regulates aspects related to the use of tax incentives for innovation. This legal document defines innovation as the conception of a new product or process of manufacturing, as well as the aggregation of new functionalities or characteristics to the product or process that implies incremental improvements (Instrução Normativa 1.187, 2011). Additionally, the aim of innovation is to give effective gain of quality or productivity, resulting in greater market competitivity (Instrução Normativa 1.187, 2011). Besides this concept, there is other important definitions included in the TII law as such show in the Table 1:

Table 1

Types of activities support by Brazilian tax incentive innovation

\begin{tabular}{ll}
\hline Basic research & $\begin{array}{l}\text { Works performed with the objective of acquiring knowledge regarding com- } \\
\text { prehension of new phenomena, with sights to the development of products } \\
\text { processes or innovating systems. }\end{array}$ \\
\hline Applied research & $\begin{array}{l}\text { Works performed with the objective of acquiring new knowledge, with sights to } \\
\text { the development or improvement of products, processes and systems. }\end{array}$ \\
\hline Experimental development & $\begin{array}{l}\text { Systematic works delineated from pre-existing knowledge, aiming at the verifi- } \\
\text { cation or demonstration of the technical or functional viability of new products, } \\
\text { processes, systems and services or, still, and evident improvement of the already } \\
\text { produced or established. }\end{array}$ \\
\hline Basic industrial technology & $\begin{array}{l}\text { Those such as measurement and calibration of machinery and equipment, the } \\
\text { project and confection of specific measure instruments, the certifying of confor- } \\
\text { mity, including corresponding tests, the normalization or technical documenta- } \\
\text { tion generated and the patenting of the product or process developed. }\end{array}$ \\
\hline Those that are indispensable to the implementation and to the maintaining of \\
installations or directed equipment, exclusively, the execution of research, de- \\
velopment or technical innovation projects, as well as human resources training \\
destined at them.
\end{tabular}

According to the Normative Instruction 1.187/11, the expenditures with technological research and development of technological innovation can be deducted from the tax base of Brazil's Imposto de Renda da Pessoa Jurídica (IRPJ) (Corporate Income Tax) and Contribuição Social Sobre o Lucro Líquido (CSLL) (Social Contribution on Net Income ${ }^{2}$ ) (Instrução Normativa 1.187, 2011).

All expenditures with $R \& D$ as those of Chart 1 can be diminish of tax base of both IRPJ and CSLL. In the same way that, there are others expenditures also tax deductible such as:

2 Both, IRPJ and CSLL are calculated based on the company's actual profit. 
laboratory exams and tests; payment of salaries, social/labor charges and technical training of personnel involved exclusively or partially in $R \& D$ projects; registration and maintenance of trademarks, patents and cultivars, even if paid abroad; technical and scientific assistance; payment of royalties due to the use of industrial patents owned by individuals or legal entities residing abroad (Lei 11.196, 2005).

In order to use TII, the firms must elaborate a technological and innovation project. Besides that, it is mandatory to perform the analytical control of costs and expenditures involved in this project (Instrução Normativa 1.187, 2011). As a result, the firms should performance a uniform and consistent methodology throughout time in order to register detailly the deductible expenditures. Additionally, the hours worked and dedicated to the innovation project must be registered in specific controls, with their respective wage value (Lei $5.798,2006)$. That must happen for all the persons involved in the innovation project, whether they are part of research staff or technical support group. Furthermore, the organization must calculate the actual profit (Lei 11.196, 2005).

The operationalization of the TIl occurs by means of the exclusion of calculation basis, either IRPJ or CSLL, of the amount corresponding to $60 \%$ of the expenditures with $R \& D$ previously showed. This percentage can be increased in two ways: first one increase in more $20 \%$ or $10 \%$ in the case of the organization having enlarged, respectively, up to $5 \%$ or above $5 \%$, the average of the number of researchers with exclusive dedication to the $R \& D$ in the current year compared to the previous year ${ }^{3}$; second one increase in more than $20 \%$ in case the organization having received the concession of any trademark, patent, or registration of plants variety (Lei 11.196, 2005).

Other instrument of the TII is accelerated depreciation of all machines, equipment, appliances and instruments purchased to be used in the activities of technological research and development of technological innovation (Lei 5.798, 2006). In this way, the integral depreciation can be done in the same year of acquisition of the tangible goods. In doing so, the net profit decrease. Consequently, this diminish both the IRPJ and the CSLL (Instrução Normativa 1.187, 2011). Similarly, the purchase of intangible goods also can suffer this type of acceleration with the same impact on net profit.

Additionally, the registration and the maintenance of trademarks, patents and plants variants done abroad with money from Brazil may be free of IRPJ, other TII benefit (Lei 11.196, 2005). Besides that the TII has other incentive, the Tax on Industrialized Product can be reduced in $50 \%$ whether the product bought is to be applied on technological research and development of technological innovation (Lei 11.196, 2005).

\footnotetext{
3 The NI 1.187 (2011) permits to be considered, for calculation means of the increment of researchers, those employers that previously collaborated with the company, but that, in a specific moment, have a change in function and work contract to that of a researcher.
} 


\subsection{COOPERATIVISM: INCOME TAX AND SOCIAL CONTRIBUTION ON NET INCOME}

The cooperativism occurs when the workers exercise the associativism. They put together the efforts of each one to built a mutual help. Thus, the persons plan a collective organization which helps them supply their needs. In this way, the property of production means is collective because the all cooperative members are owners of the means of production and can infer-or interfere-directly in the destiny of the enterprise (Davis \& Bialoskorski, 2010). Because of this, each associated has the right to a singular vote, a fundamental principle of cooperativism.

The Brazilian Law 5.764, from December 16th, 1971, defines the National Policy of Cooperativism and institutes the legal regime of cooperatives societies in Brazil. According to this regulation, cooperatives are property of their associates and serve to provide services that improve their conditions. As a result of, transactions done within cooperative, for example between one member and the cooperative, in order to achieve the aim of this organization is not considered market operation. In this sense, it is necessary clarify the kind of acts performed by cooperatives.

On one hand, the acts celebrated between the associates and the cooperative are called of the Cooperative Acts (CA). These acts refer to the operations between the cooperative and its associates or vice-versa, as well as amongst cooperatives when they work together as a single organization (Lei 5.764, 1971). In this case both cooperatives and members run in order to achieve advantage economic through mutual help without to aim profit. Since the CA is not a market transaction and don't generate profit, then it doesn't suffer tax effect of both IRPJ and CSLL.

On the other hand, non-cooperative act (NCA) occurs, in the particular case of agroindustry, in the instant the cooperatives perform transactions with non-associates in order to complement the scale of industrial production, or when they offer goods and services to non-associates (Lei 5.764, 1971). Since only NCA is source of market transaction with generation of profit, then, only it can suffer incidence from IRPJ and CSLL.

The Normative Opinion of the Coordinator of the Taxation System 73/1975 points that Cooperatives Societies must segregate the revenues and costs in two separate groups, or in one which register the cooperative acts or in one which account the non-cooperative acts (Parecer Normativo do Coordenador do Sistema de Tributação 73, 1975). However, there are expenditures that deal in the same time both cooperative acts and non-cooperative acts and because this can't be accounted integrally or in one or in another act. In this case, this kind of expenditure should be arbitrarily connected to one type of the act (Parecer Normativo do Coordenador do Sistema de Tributação 73, 1975). In order to do this, the cooperative 
segregate this sort of expenditures according the weight of participation that each act has on the total result economic of cooperative.

This research finds that the segregation of the expenditures according acts interferes in the effect of the TII incentive. Since cooperatives connect all expenditures in one of acts, so this impact the effect that the TII has on the save of cooperative tax payment. So, the conclusion is of that while the cooperative proceeds their normal accounting, their TII benefits decrease. In practice R\&D expenditures is divided to be link either AC and NCA. Consequently, the R\&D connected with former should not be offer to suffer TII effect because this can occur only with the part attach to last.

Table 2 shows a hypothetical example which is result of the current research. In this away, it is imaged that expense with R\&D of cooperative is equal $\$ 1.000$. Assuming that such expenses are in accordance with the TII legislation criteria, $80 \%$ of this amount is deductible. Then, $\$ 800$ can be decreased on the IRPJ and CSLL calculation base. However, only in the case of cooperatives, these $\$ 1$ thousand should first be reduced according to the ANC share of the cooperative's economic result. For example, if the NCA is $30 \%$, only $\$ 300(=\$ 1,000$ (0.3)) can be used to calculate the benefit of TII. This means that $\$ 240$ ( $=\$ 300(0.8)$, instead of $\$ 800$, would be used as benefit came from TII. Meanwhile, the normal capitalist company could use the $\$ 800$ in its TII access.

Table 2

Reduction of tax benefits related to Cooperative Acts

\begin{tabular}{ll}
\hline Expenditure with R\&D & 1,000 \\
\hline Deductible amount other types of companies (80\%) & 800 \\
\hline $\begin{array}{l}\text { Deductible amount R\&D cooperative - only the per- } \\
\text { centage referent to the Non-Cooperative Act }=30 \%\end{array}$ & $800 *(0,3)=240$ \\
\hline
\end{tabular}

Traditional big capitalist companies access public incentives easer cooperatives. Nevertheless, the Brazilian agri-food industry improves their competitive advantage through investments on innovation. In few words, innovation leads to extraordinary profits and avoids lose clients and bankrupt. However, the innovation activity is surround by many risks. Because of this, the entrepreneur tends to do less investing in such activity. In order to overcoming the barriers which difficult the innovation, the government offers innovation policies, as the tax incentives, to balance the risks and uncertainties intrinsic on innovation activities. In this sense, Brazilian government has a robust program of TII.

The cooperative cannot use all the potential of this public policy because of their specific regulation. First of all, it is necessary know the practices performed by farming cooperatives regarding the tax, accounting and administrative management linked to the Tax Incentive for Innovation. From this, it will be possible to suggest a improvements in the cooperatives access to the TII. 


\section{RESEARCH METHOD}

The analysis of theory suggests that the innovation policy offers several tools to encourage innovation in the organizations. However, the legal regime of cooperatives has tax and accounting specificities that restrict the use of TII by cooperatives. Even if such organizations have done innovation, only 4 out of a universe of almost 1 thousand accessed TII in 2014 (Ministério da Ciência e Tecnologia [MCT], 2014). Additionally, this can be the reason that studies on such topic, in Brazil, are scarce. In this away, the present paper showed management practices regarding the access of cooperatives to the TII. In addition that, it was inferred that innovation activities in cooperatives receive a minor support from the government than in other forms of organizations.

The present paper is characterized as a research of qualitative nature whose investigation method selected was the single case study. This choose was done in order to give to the work systemic and interdisciplinary view. In such method, the sample is analyzed to verify if it is sufficiently significative. If this is confirmed, it is preferable adopt an approach qualitative than a sampling logic. In such circumstance, the typical criteria regarding the size of the sample are irrelevant, once the case provides sufficient information to contemplate the research constructs identified and, thus, achieving the research goals (Eisenhardt, 1989).

In this sense, it was analyzed critically the Tax Incentive for Innovation in the context of a cooperative organization. It was done through of an in-depth study regarding the tax, accounting and administrative management linked to the Tax Incentive for Innovation. Besides that, literature about innovation policies rarely focus on organizational management regarding TII. Instead that, the studies focus on evaluating the average of some quantitative variables. Due this, it is necessary explore more such topic in order to deepen the theory about the relation between innovation policy and cooperative (Tripodi, Fellin, \& Meyer, 1975).

The unit of analysis selected in this case study was a Central of Agroindustry Cooperatives in the state of Rio Grande do Sul, in Brazil. Since the Central fills the criteria requested by qualitative method, it can be the analysis unit because it. The sufficiency of that analysis unit occurs because it congregates a group of 30 agroindustry cooperatives. This number represent $23 \%$ of all farming cooperative located in the Estado Rio Grande do Sul (State of Big River of South) (which is the State where the analysis unit is located).

Besides this, it has factories of dairy products whose processing capacity is of 2.2 million liters of milk per day. Hence, it is considered the largest industrial park of powdered milk in Latin America. Moreover, this organization has a department of Research \& Development (R\&D) which transmit knowledge to be applied in its associated cooperatives. In 2018, the Central has had 617 direct collaborators and more than 170 thousand associated 
rural producers located in 350 municipalities, according one of interviewers. These members provide raw material for the Central.

Moreover, the Central has importance in terms of knowledge production and diffusion of technology and innovation, since it has a department of $R \& D$ with 21 researchers distributed in 5 innovation projects. Then, the Central transfers the results of the researches produced in its $R \& D$ unit for the its associate cooperatives. Consequently, thousands of rural products have had its production improved, according one of interviewers.

It was also conducted data secondary analysis. In this case, the Relatório Anual da Utilização de Incentivos Fiscais 2014 (Annual Report on Use of Tax Incentives 2014) was investigate. The 2014 Report it was the last published by Ministério da Ciência e Tecnologia do Brasil-MCT-Brazilian Ministry of Science and Technology) in order to consolidate data regarding innovation activities and the tax impact of all the organizations benefited by the TII. Then, it was observed that only 4 cooperatives organizations, include all branches, accessed this policy in Brazil, among these the Central used as analysis.

Others Central documents also composed the list of secondary data such as: the balance sheet of the analysis unit, the $R \& D$ project, the cost center for expenditures with innovation activities and the spreadsheets referring to tax calculations on tax incentive. Apart from the data mentioned, was also consulted the legislations relevant to TII in the Federative Republic of Brazil. It was applied on all those documents the orientation of Yin (2010). This author suggests that is necessary proceed either a stability review (verification of documents in several times) and a accuracy process (detailed and exact information of the events researched). So, those two quality criteria were applied on all documents.

A special attention was put on the primary-data collect instruments. They were submitted to the evaluation of doctor professors and specialists with big skill of in the topic researched. In this way, it was sent a email with the questionnaires for this professors evaluate them. In particular they were revised by an auditor of the State Revenue of Rio Grande do Sul (Brazil). Besides that, the documents refereed were examined also by both a professor in cooperativism and an accountant specialist in tax on cooperative. In this sense, the recommendation of Bradburn, Sudman, e Wansink (2004) and Seidman (2006) was followed, which recommend to submitting the research tool to the evaluation of specialists for the content analysis. After accepted the suggestions and corrections, the revised scripts were submitted to pre-tests with managers of the agricultural sector. Finally, when it was finish all those phases, the collect instrument of primary data was considered validated and revised.

Thus, the exploratory phase of data collection occurred through some semi structured interviews. In doing so, it was deepened the knowledge about the TII management in the Central studied. Therefore, interviews with the following managers were carried out: tax manager, legal manager, research unit director, processing industry manager and purchasing 
manager. Moreover, neutral observation in different informal contacts with interviewed was carried out in order confirm the research results (Yin, 2010).

The data obtained from the interviews was confronted with the theoretical framework in order to verify its connection with the specialized literature. Moreover, the perceptions of the interviewees were analysis by content analysis technique, as guided by Bardin (2011). In addition, it was performed a triangulation of the data considering data raised of different sources either primary and secondary, following the suggestion of Yin (2010).

\section{DATA ANALYSIS}

In 2018, the R\&D department of the unit analyzed developed 5 innovation project distributed amongst different area as entomology, phytopathology, soil fertility, forage species improvement, weeds, according the research unit director. Such researches started some years ago and yearly the Central budget approve a financing for $R \& D$ department as explained by tax manager. The balance sheet of the cooperative showed that the expenditure with those 5 projects was $\mathrm{R} \$ 2,02$ million in 2015. However, while the TII permits other organizations to reduce $80 \%$ of this amount, the cooperative cannot do this. This last economic organization has tax and account rules which enforce a reduction of benefits that the cooperatives would can receive.

The research performed by the Central Cooperative is relevant, once its result is disseminated among several associate cooperatives according the managers of Central. Consequently, the knowledge generates by Central is applied in thousands of properties whose owners are members of cooperatives. Besides that, the Central managers reported that the choices of the research lines of the Central is decided in accordance with the technological needs of the associates cooperates. Therefore, the $R \& D$ department follows directly the needs of technical solutions of the rural producers in order to guide its studies as remarked by research unit director.

According legal manager, the Cooperative Central write an innovation project to specifically deal to the TII. Since the Ministry of Science and Technology of the Federal Government of Brazil order that all organization must deliver such project as control process, it is mandatory (Lei 11.196, 2005). Such document is elaborated by an external consulting company hired by Central. According the tax manager of the Central is convenient outsource the project elaboration because the assistant firm follows the changes in regulations and transmits them for the Cooperative.

Moreover, the outsourced company hired to manage the innovation project of Central performs fill and delivery of all the documents requested by government as reported by tax manager. Besides that, when is necessary to elaborate appropriate answers to public agency 
the firm hired do this. The external consultant receives of Central information regarding innovation activities performed, the amounts spent with research and the tax saved. With those data the innovation project is elaborated, as state by tax manager. Furthermore, the cost with the consulting services is low, since the remuneration is a percentage of the tax saved by means of the tax benefit. In other words, the Central don't need to pay such services before obtaining the tax savings according the tax manager.

The tax manager state that there are meetings between the external consultant and the Cooperative Central, intermediated by the tax manager, in order to detail the evolution of the R\&D projects. Therefore, there is an integration between the researchers and the external company, mainly for discussions about the relevant points of the innovation and technological activities. Since the consulting company has been developing such work since 2013, without any disparagement, it has credibility with its client. Finally, when the innovation project is concluded, it is sent to the Ministry of Science and Technology for its evaluation. Therefore, the project can be approval or not according the reported by cooperative stuff.

The Ministry of Science and Technology receives the innovation project until June 30th of each year. Next, this government agency emits an opinion which approval partially or totally the project. The interview displayed that, in generally, the public agency observes if the innovation activities reported are in accordance with the law criteria in order to performance the deduction of the expenditures with $R \& D$. In some cases, the government requested adjust to Central.

The interaction with regulatory agencies occurs by electronic means, by which there is document transference, without the need for face-to-face visits, according tax manager. A point to be highlighted is that the cooperative does not need previous approval of the Ministry of Science and Technology to perform the accounting deductions regarding the TII. Instead, after performing effectively the expenditures with $R \& D$, these are deducted in the tax calculation in the same year in which they were executed. After, it is reported to the Ministry in the following year (Lei 11.196, 2005).

The Central delivers to Federal Revenue Service of Brazil its Tax Accounting Bookkeeping which is attached the tax saving information derived from the use of the TII. However, the detailed worksheets regarding the spending operations with $R \& D$ remain filed in that organization, as was explained by tax manager. So, the authority may do inspection face its desire. In any case, there is not records regarding the contestation by the governmental fiscal authority about tax reduction came from TII. Since the authority of the fiscal department have had confidence in the work of Ministry of Science and Technology, it doesn't ask for more detail about the TII process.

In the interviews was stated that the activities of the Central $R \& D$ unit are controlled by a center of specific costs and, thus, are easily identified in order to realize the calculate process which lead to the tax benefits of the TII. Still, the center of specific cost already works 
before the incentives for innovation to be used by Central. Due to, the accounting procedures previously established in the routine of the Central were sufficient to this organization deal with accounting management regarding to the TII expenditures.

Apart from, each project of $R \& D$ has its specific cost center, according purchasing manager. This person also reported that the cost centers are supervised by a manager and accessed via an electronic platform interconnected with several other areas of the Central. So, when a researcher needs some material for his study, he does its require via a specific software. Consequently, this request is analyzed by the superior managers. This last person approvals the referred request and sent it to the purchasing department.

There is a direct relation between the researcher and the purchasing department. According the purchasing manager the purchase of any material follows some steps. First of all, any material pertinent to the research that needs to be purchased is duly registered in advance and with detailing of features on an electronic platform. This way, the technical area responsible for the innovation activities consults in the market the ideal characteristics of the requested material and report it through electronic way. Immediately the purchasing department visualize the material requested. In an effort to have sure that the purchase will be done correctly, the buy department consults the R\&D unit before acquiring the product. As a result of the intense relation between the researcher and other areas of the Central, the former develops administrative and management skills that include either processes and operationalization of electronic platforms and buy management.

Some conclusion can be done. On the one hand, the accounting and administrative management procedures which Central have done are perfectly compatible with all operations involved in the access to TII. Hence, the routines previously established regarding either administrative or accounting have been enough to access the TII. On the other hand, the amounts spent on $R \& D$ are annually planned and have a budget line whose worth is stable throughout time. In this sense, there is a routine in terms of expenditures with technology activities with predictable resources. As a result, the expenditures with $R \& D$ area are stables.

It is important remark that the production units considered for deductions from TII refer to all those units which generate taxes, according tax manager. In other words, all the tax arised in different economic activity within of Central are used in the deduction process involved in the TII access. This means that the Taxpayer's Identification Number aggregate the tax arise from different Central economic activities. This is important because even if the unit which make the innovation doesn't originated tax, still the Central can access the TII as long as other unit within Central have arisen it. In other words, the tax generated regardless of local observation where expenses with technological $R \& D$ were performed. In this way, the tax calculations are centralized in an accounting unification of the matrix. 
Figure 1 is based on the real spreadsheets which concern to the tax deductions regards to the TII of Central. Notwithstanding it was possible analysis the Central original document, the number within the sheet is just examples. So, Figure 1 exemplifies the organization chart regarding the tax origin and the innovation activities in different production areas of the unit. In is possible see that the industrial, retail and transportation units generate tax, since their activities involve NCA. Deductions from TII on the calculation of this tax have been done, even if the expenses with $R \& D$ occur in a unit that does not generate taxes, in the example, at R\&D department.

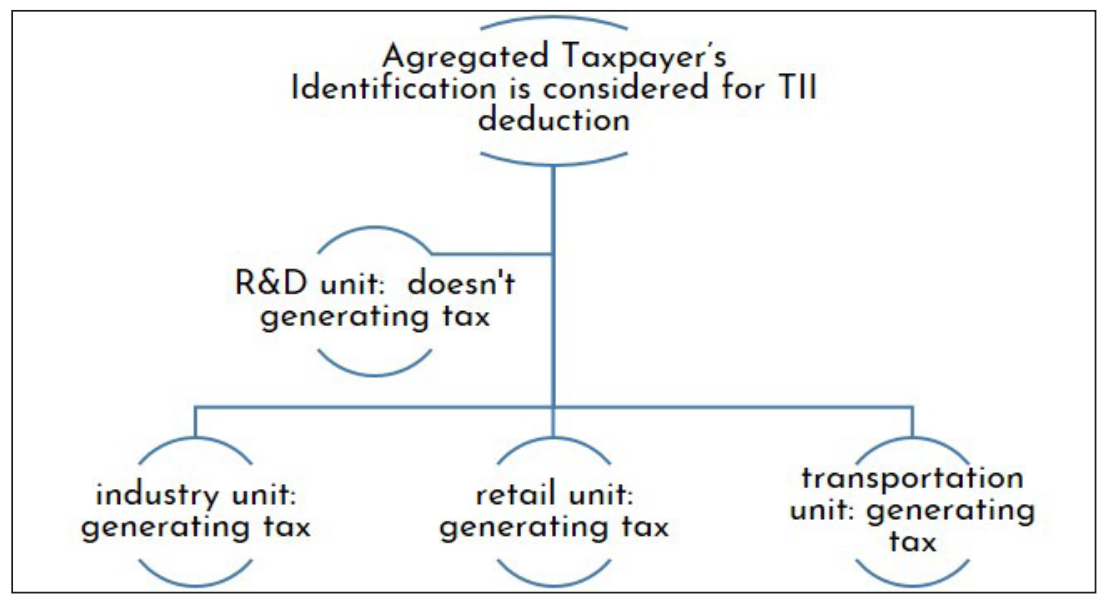

Figure 1. Production units of a cooperative and the generation of taxes.

Figure 2 demonstrates, in brief, as the Central do the tax, accounting and administrative management linked to the Tax Incentive for Innovation (TII). So, the Figure 2 is the result of analysis of all documents investigated. Hence, it was elucidated how the Central deal with several process involved in access to the TII. Specifically, Figure 2 was designed considering the case of the Central analyzed in the research.

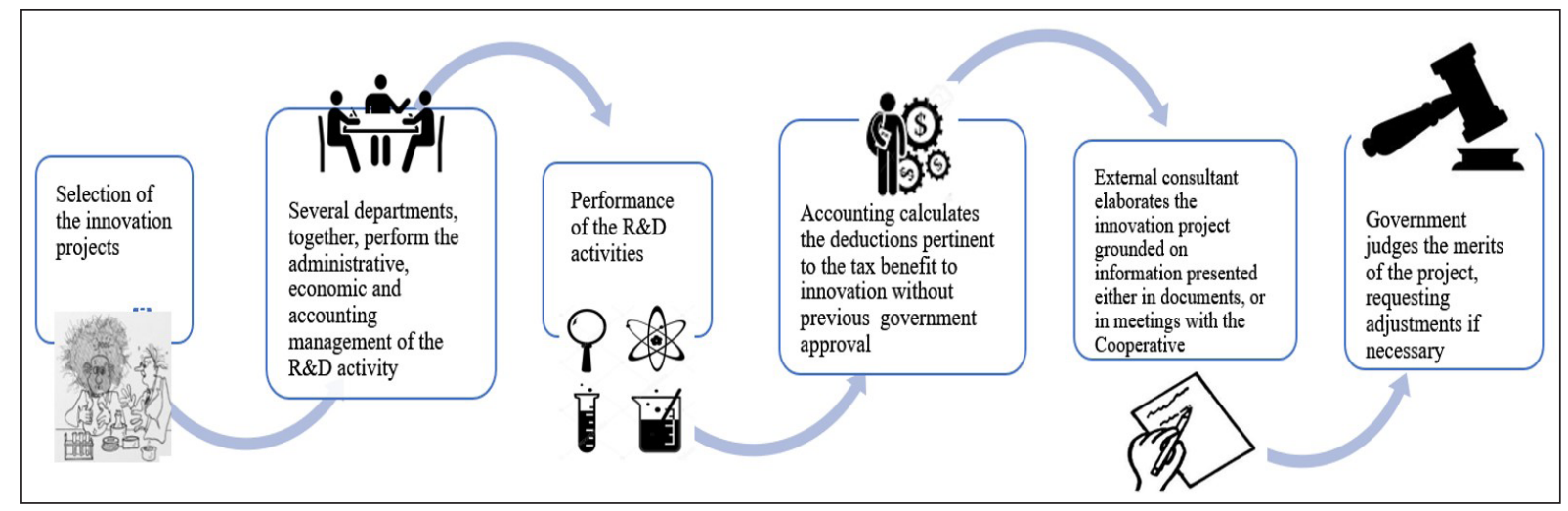

Figure 2. Chain of operations related to the benefit of the Tax Incentive for Innovation. 
First of all, the Cooperative Central selects the innovation project according to the technical needs referenced by their associates cooperatives. Following that, different departments of the Central work together on the coordination of $R \& D$ project management. As a result, it is agreed how different aspects of innovation project will be deal such as the purchases or the recordings of innovation activities in the pertinent control documents.

Simultaneously, in the R\&D unit, the researchers perform their activities. With data regarding innovation expenses, the accountant calculates the benefit achieved from the TII. After that, all the data about both the innovation project and TII benefits are passed to the external consultant. This agent arranges whole necessary process to deal with Brazilian Ministry of Science and Technology in order to access TII. So, the public agent judges the project which can be approved, disapproved, or even returned to the Central to do some requested alteration.

\subsection{TAX MANAGEMENT}

The source of all data worked in this subsection came from the interview which the respondent was the tax manager because the main finding of the paper is regarding to relation between TII and cooperative. Particularly, it is important deal with CA and NCA in order to understand the issues about the use of the TII by a cooperative. Since cooperative segregation its results economic either CA e NCA, it interferes in the effect the TII has on the tax saving of the cooperatives. How it was already explained, there is a restriction in the access to the incentive (factor that reduces the tax saving) by cooperatives business model.

In practice, the cooperative abates only one part of the amount expenditure with $R \& D$. That is, the expenses with innovation is reduced according the proportional that the NCA share in the total result of cooperative. In other words, the total amount spent with R\&D cannot be used to deal with TII benefits, but it must be diminished following the proportionality that NCA represent, such as is display in the example on the Table 3 : 
Table 3

Cooperative and Tax Inventive to Innovation: tax result \$

\begin{tabular}{|c|c|c|c|c|}
\hline \multirow{2}{*}{\multicolumn{3}{|c|}{$\begin{array}{l}\text { Expenditure with R\&D } \\
\text { deductible amount - other types of companies ( } 80 \%)\end{array}$}} & \multicolumn{2}{|l|}{1.000} \\
\hline & & & \multicolumn{2}{|c|}{800} \\
\hline \multicolumn{3}{|c|}{ Amount deductible $R \& D$ cooperative (reducer) } & \multicolumn{2}{|c|}{$800^{*}(\%$ NCA) } \\
\hline & \multicolumn{2}{|c|}{ with reducer } & \multicolumn{2}{|c|}{ without reducer } \\
\hline Net income/General remainder & 5000 & 5000 & 5000 & 5000 \\
\hline$\%$ Non-Coop. Act & 0.20 & 0.80 & 0.20 & 0.80 \\
\hline Net income & 1000 & 4000 & 1000 & 4000 \\
\hline Spent with innovation & 160 & 640 & 800 & 800 \\
\hline Tax base & 840 & 3360 & 200 & 3200 \\
\hline IRPJ - $15 \%$ & 126 & 504 & 30 & 480 \\
\hline Additional IRPJ - 10\% & 84 & 336 & 20 & 320 \\
\hline CSLL - $9 \%$ & 75.6 & 302,4 & 18 & 288 \\
\hline Tax to be paid & 285.6 & 1142.4 & 68 & 1088 \\
\hline \multicolumn{5}{|c|}{ Difference in tax saving $=($ tax with reducer $)-($ tax without reducer $)$} \\
\hline Non-Coop. Act & \multicolumn{2}{|c|}{0,20} & \multicolumn{2}{|l|}{0,80} \\
\hline Difference & \multicolumn{2}{|l|}{217.6} & \multicolumn{2}{|l|}{54.4} \\
\hline Variation \% & \multicolumn{2}{|l|}{$-76 \%$} & \multicolumn{2}{|l|}{$-5 \%$} \\
\hline
\end{tabular}

In the hypothetical example of Table 2, the same amount spent on technological R\&D would result in different tax savings for the cooperative, according to the percentage of CA and NCA. Two hypothesis of non-cooperative acts participation were used, one of $20 \%$ and another of $80 \%$, to deal with different situation. The former percentage is closer to the reality of the farming sector and last one is closer of the health sector, considering the Brazilian case. Moreover, it is called expenses reducer the result of the multiplication of the NCA by the amount spent on $R \& D$. It is verified that with the reducer factor, the cooperative pays $76 \%$ or $5 \%$ more of taxes, respectively, to the NCA of $20 \%$ and $80 \%$, face with the situation without reducer factor.

As a logic result, if the cooperative is highly innovative, but without NCA practice, then, the benefits from TII cannot be accessed by it. In order to see this penalty run in the cooperative just calculate the expenses reducer face an one NCA equal zero, i.e. $1,000 * 0=0$ (where 1,000 is the spent with innovation; 0 is the share of NCA). It means that there is zero of expenses with innovation that can be deduced according that TII permitted. In others words, even that the cooperative attends all requested criterial to use TII, but without NCA, automatically this organization will not be beneficiated. That opens a debate that will likely generate diverse positions, given its interpretation possibilities.

One possible statement is that the accounting rules of cooperative must be followed always, without exception. In this case, the regulations pertinent order the linking of the total of the expenditure of the cooperatives to one of the respective acts, cooperate and noncooperate. Consequently, the expenditures on innovation connected to CA would cease to 
be used for deduction purposes. In doing so, the accounting standards would be met. Hence, just one part of $R \& D$ expenses would be excluded such as in the Central case analyzed before. However, for such treatment, it must be ignored relevant economic variables that substantiate the innovation policy of the country.

Innovation activities are considered risky because their final goal, the innovation, can be frustrated. Thus, the investment on them can result in failure and financial loss (Bowers \& Khorakian, 2014; Nelson, 2006; Freeman \& Soete, 2008). Besides that, their development process is long-term, requiring a space of time above what the entrepreneur would expect to obtain a financial return (Freeman \& Soete, 2008). Furthermore, the cost to deal with innovation project is so high (Rosenberg, 2006). Because of this, the government creates incentives to encourage the innovation, on of them is the TII. In the end, innovation policy is used by a big range of countries in order to achieve the development.

In order to government to achieve its aim of promote development through innovation, it is better permit the fully utilizing the expenses with $R \& D$, without the reducer which penalty the cooperatives. In this way the entrepreneur will carries out more innovation activities helping the country became more competitive through innovation. So, if the barrier that diminish the benefits that cooperatives receive from TII was removed, the government would achieve better its aim regarding innovation policy.

It is important remark that any other no-cooperative organization able to use the TII deduces completely the expenditure with $R \& D$. So, just the cooperatives are impeded since they must reduce of the R\&D expenses according of the NCA share. In face of this situation other organizations deduce as possible its expenditure with $R \& D$, but the cooperatives do this proportionality less. Therefore, it may be a discrimination. Because if the cooperative is engaged in make innovation, why does it cannot use its expenses with innovation as such other organization?

Two logical conclusions can be done. First on, there is a trade-off between the accounting rules and innovation encouragement. Because if the former is applied the last one works less. Second one, highly innovative cooperatives, but without the NCA, have not possible of to use TII, even if they contribute to elevate the rate of innovation in the country. In this case, the policy is being a tautology to measure how much there is of cooperative and non-cooperative act. But this function is not the aim goal of this policy which search potentialize the innovation.

In accordance the economic view $100 \%$ of the expenses with innovation should be deducted from the calculation basis of taxes. But if whole expenditure was deduced, it would be to generate an exception for the $R \& D$ expenditures which would not follow the accounting rules. In face of exposed, it is suggested a discussion between several actors involved in the innovation system in order to debate this situation. In other words, a meeting amongst 
specialists in technical-innovative, legal and political matters of the cooperatives universe may be done with a view to leave back this problem. Therefore, overcoming the simple choice of following the numerical purism of the accounting rule, will lead to a debate about the importance of innovation in the cooperative environment.

Now it summarized some findings of search. First one, the paper broadens the understanding regarding the relation between of a Cooperative Central and the innovation policy. Second one, in the case studied, the result of the R\&D is transferred to rural producers, improving, possibly, their productivity. Moreover, the choice of the technological projects developed is based on the needs of technical problems solution of the cooperates. Third one, there is a huge collaborative work amongst several Central department in order to manage the innovation project. So, the accounting and administrative management has a routine whose interactions function in a pertinent form, with few adjustments to be made. In addition, an external consultant helps in the work of access to the TII.

In fourth place, it is necessary improves the access of cooperatives to the TII to guarantee that this organization receive more efficiently the benefits from TII. In other words, it was found the need of change some tax aspects leading to the increase of encouragement to the innovation in the cooperative environment. Therefore, it is necessary a debate involving various actors of the innovation system in which cooperatives are involved in order to discuss about the penalties which the cooperatives deal during its access to the TII. In conclusion, it is necessary to grow the debate that will lead to the decision of simply choosing for the pure accounting rule or increase the benefits from TII. In conclusion, it is necessary debate that will lead to the decision of simply choosing for the pure accounting rule or increase the benefits from TII that can be use by cooperatives.

\section{CONCLUSION}

The technology generated by the Central studied supports the productions of hundreds of small producers, which helps potentialize the wage of the cooperates. The Central R\&D avoids that cooperative member buys technology would from other firms through market operation. Instead that, the Central offers new knowledge to its associated free of charge. So, in the process of spreading technology from Central Cooperative to rural producer, others singulars cooperatives, may have an important role in the dissemination of technology. It means that may there is a chain which the technology pass going and this need be more studied. Additionally, there is a contribution that still needs to be measured, of the cooperatives system in the improvement of the National and Regional System of Innovation.

Given the importance of cooperatives in the Brazilian rural sector, such organizations start to invoke innovation policies to broaden their productivity, profitability, market 
participation and formation of competitive advantages. However, there are barriers that restrict of cooperatives access to those policies. In the midst of this access problem these barriers should better identified and discussed like was done about one of them regarding to the TII in this paper.

It was evidenced that there is a maladjustment between the legislations that regulate the innovation policy and the ones that standardize the universe of cooperatives. Since the first were elaborated without consideration to the specificities of the latter. Consequently, the agencies that regulate the incentive for innovation confront the nature of the cooperatives. Since there is a confront between the innovation policy and the nature of the cooperatives, the capacity that such organizations have of to appropriate some of this policy decreases.

The restriction in the use of the TII by cooperatives prevents them to fully make use the tax benefit in the same way that other organizations do. Someone may not see problem in this because the cooperatives have part of its operation tax immune. But it is important consider also other reality, i.e. there is specific rules that only cooperative should follow.

The non-taxation of IRPJ and CSLL on CA for cooperatives was granted to them due to the special nature of their operations. In such case, the cooperative is subject to specific rules, not imposed to other organizations. For example, the cooperative profit is regulated by government. While the others capitalist firm is immune of rules on profit, the cooperatives follow rules which describe the destination of its economic results. In others words, other organizations have free choose about what do with its profits, but the cooperatives must follow law which limit decision regarding profit application. For example, the cooperatives need to use part of their profit to constitute the Fundo de Assistência Técnica Educacional e Social (Educational and Social Technical Assistance Fund).

Thus, the cooperatives have specific tax treatment because of its particular natures. These rules differentiated cannot lead to punishment of the cooperatives regarding an others types of tax incentives, as occur with the TII. As a result, the differenced taxing on cooperative revenue is reversed due to barriers to access the TII. Hence, the cooperative loss its tax differentiation because on the one hand it pays less revenue tax, on the other hand it receives proportionality minor TII.

In synthesis, the TII legislation confronts the specific tax and accounting regulations which are followed by Cooperatives. Therefore, it is important to promote a debate involving various actors, such as the government and entities of the cooperativism system, to search for a solution to the problem of the restrictive factors imputed to cooperatives in access to TII. Since, innovation policy is one of the propulsion factors for the development of nations, the government must rethink the limited access of Brazilian cooperatives regarding TII.

The present research permitted check as a Cooperative Central have been management its access to an innovation policy. Thus, the objective of elucidating the practices performed 
by farming cooperatives regarding the tax, accounting and administrative management linked to the TII was accomplished, given that the processes practiced by the research unit to access the TII were described in detail. Furthermore, the tax, accounting and administrative management that have been operated by Central before it accesses the TII were able to meet the new specific acts related to the use of that policy. So, it was not necessary implement new processes.

\section{REFERENCES}

Bardin, L. (2011). Análise de conteúdo. São Paulo: Edições 70.

Bialoskorski, S., Neto. (2016). Economics and management of cooperatives organizations. (2nd ed.). Saarbrucken: LAP Lambert Academic Publishing.

Bowers, J., \& Khorakian, A. (2014). Integrating risk management in the innovation project. European Journal of Innovation Management 17(1), 25-40.

Bradburn, N., Sudman, S., \& Wansink, B. (2004). Asking questions: The definitive guide to questionnaire design for market research, political polls, and social and health questionnaires. San Francisco: Jossey-Bass.

Caldeira, A. C. (2007). Rota do cooperativismo: De Rochdale à estratégia negocial cooperativa. São Paulo: Pensamento e Realidade.

Cimoli, M., Ferraz, J. C., \& Primi, A. (2005). Science and technology policies in open economies: The case of Latin America and Caribbean (Serie desarrollo productive, n. 165). Santiago de Chile: Cepal.

Davis, P., \& Bialoskorski, S., Neto. (2010, jan./jun.). Governança e gestão de capital social em cooperativas: Uma abordagem baseada em valores. ESAC-Economia Solidária e Ação Cooperativa, 5(1), 1-24.

Eisenhardt, K. M. (1989). Building theories from case study research. Academy of Management Review, 14(4), 532-550.

Freeman, C., \& Soete, L. (2008). A economia da inovação industrial. Campinas: Editora Unicamp.

Ganiyu, R. A., Barbara, O. A., \& Paul, O. O. (2018). Trends in business performance measurement: A literature analysis. International Journal of Social Sciences and Humanities Review, 8(1), 151-160. 
Grazzi, M., \& Pietrobelli, C. (2016). Firm innovation and productivity in Latin America and the Caribbean. New York: Springer Nature: Inter-American Development Bank.

Instrução Normativa 1.187, 2011.

Lei $5.764,1971$.

Lei 5.798, 2006.

Lei 11.196, 2005.

Lome, O., Heggeseth, A. G., \& Moen, O. (2016). The effect of R\&D on performance: Do R\&D-intensive firms handle a financial crisis better? The Journal of High Technology Management Research, 27(1), 65-77.

Ministério da Ciência e Tecnologia. (2014). Relatório Anual da utilização dos incentivos fiscais à inovação tecnológica ano-base (N. CGIT/COID RA-LB-2014-SETEC/CGIT/COID).

Nelson, R. R. (2006). As fontes do crescimento econômico (Clássicos da Inovação). Campinas: Editora Unicamp.

Organização das Cooperativas Brasileiras. (2017). Agenda institucional do cooperativismo. Brasília, DF: OCB.

Organização das Cooperativas do Rio Grande do Sul. (2017). Expressão do cooperativismo gaúcho. Porto Alegre: OCRGS.

Parecer Normativo do Coordenador do Sistema de Tributação 73, 1975.

Rosenberg, N. (2006). Por dentro da caixa-preta- tecnologia e economia. São Paulo: Editora Unicamp.

Schneider, J. O. (2010). Educação e capacitação cooperativa: Os desafios no seu desempenho. São Leopoldo: Editora Unisinos.

Schumpeter, J. A. (1982). Teoria do desenvolvimento econômico (Coleção Os Economistas). São Paulo: Abril Cultural. 
Seidman, I. (2006). Interviewing as qualitative research: A guide for researchers in education and the social sciences. New York: Teachers College.

Silva, C. L. da. (2017). Competitividade e estratégia empresarial: Um estudo de caso da indústria automobilística brasileira na década de 1990. Revista da FAE, 4(1).

Triguero-Cano, A., \& Cuerva Narro, M. C. C. (2011, October). El cooperativismo agroalimentario ante el reto de la globalización: "Renovar-se o morir". Revista de Economía Pública, Social y Cooperativa, (72), 97-124.

Tripodi, T., Fellin, P., \& Meyer, H. J. (1975). Análise da pesquisa social: Diretrizes para o uso de pesquisa em serviço social e ciências sociais. Rio de Janeiro: Francisco Alves.

Warda, J. (2005, June). Measuring the Value of R\&D Tax Provisions A Primer on the B-index Model for Analysis and Comparisons (OMC Working Group on "Design and evaluation of fiscal measures to promote business research, development and innovation"). JPW Innovation Associates INC.

Yin, R. K. (2010). Estudo de caso: Planejamento e métodos. (4a ed.). Porto Alegre: Bookman.

\section{Como citar este artigo:}

\section{ABNT}

CALZOLAIO, Aziz Eduardo; MENDINA, Heitor Jose Cademartori. Access of cooperatives to the Tax Incentive for Innovation in Brazil. RACE, Revista de Administração, Contabilidade e Economia, Joaçaba: Ed. Unoesc, v. 18, n. 2, p. 207-230, maio/ago. 2019. Disponível em: http://editora.unoesc.edu.br/index.php/race. Acesso em: dia/mês/ano.

\section{APA}

Calzolaio, A. E., \& Mendina, H. J. C. (2019). Access of cooperatives to the Tax Incentive for Innovation in Brazil. RACE, Revista de Administração, Contabilidade e Economia, 18(2), 207-230. Recuperado de http://editora.unoesc.edu.br/index.php/race 
